\title{
The influence of gas-particle partitioning and surface-atmosphere exchange on ammonia during BAQS-Met
}

\author{
R. A. Ellis ${ }^{1}$, J. G. Murphy ${ }^{1}$, M. Z. Markovic ${ }^{1}$, T. C. VandenBoer ${ }^{1}$, P. A. Makar ${ }^{2}$, J. Brook ${ }^{2}$, and C. Mihele ${ }^{2}$ \\ ${ }^{1}$ Department of Chemistry, University of Toronto, 80 St. George St., Toronto, ON, M6P 2S1, Canada \\ ${ }^{2}$ Environment Canada, Science and Technology Branch, Air Quality Research Division, 4905 Dufferin St., Toronto, ON, \\ M3H 5T4, Canada
}

Received: 1 September 2010 - Published in Atmos. Chem. Phys. Discuss.: 20 September 2010

Revised: 18 December 2010 - Accepted: 20 December 2010 - Published: 7 January 2011

\begin{abstract}
The Border Air Quality and Meteorology study (BAQS-Met) was an intensive field campaign conducted in Southwestern Ontario during the summer of 2007. The focus of BAQS-Met was determining the causes of the formation of ozone and fine particulate matter $\left(\mathrm{PM}_{2.5}\right)$, and of the regional significance of trans-boundary transport and lake breeze circulations on that formation. Fast $(1 \mathrm{~Hz})$ measurements of ammonia were acquired using a Quantum Cascade Laser Tunable Infrared Differential Absorption Spectrometer (QC-TILDAS) at the Harrow supersite. Measurements of $\mathrm{PM}_{2.5}$ ammonium, sulfate and nitrate were made using an Ambient Ion Monitor Ion Chromatograph (AIM-IC) with hourly time resolution. The median mixing ratio of ammonia was $2.5 \mathrm{ppb}$, with occasional high spikes at night resulting from local emissions. Measurements were used to assess major local emissions of $\mathrm{NH}_{3}$, diurnal profiles and gas-particle partitioning. The measurements were compared with results from A Unified Regional Air-quality Modelling System (AURAMS). While the fraction of total ammonia $\left(\mathrm{NH}_{\mathrm{x}} \equiv \mathrm{NH}_{3}+\right.$ $\mathrm{NH}_{4}^{+}$) observed in the gas phase peaks between 0.1 and 0.8 , AURAMS tended to predict fractions of either less than 0.05 or greater than 0.8 . The model frequently predicted acidic aerosol, in contrast with observations wherein $\mathrm{NH}_{\mathrm{x}}$ almost always exceeded the observed equivalents of sulfate. One explanation for our observations is that the net flux of ammonia from the land surface to the atmosphere increases when aerosol sulfate is present, effectively buffering the mixing ratio of gas phase ammonia, a process not included in the model. A simple representation of an offline bi-directional flux parameterization using the ISORROPIA thermodynamic model was successful at reducing the population of zero gas fraction points, but not the higher gas fraction points.
\end{abstract}

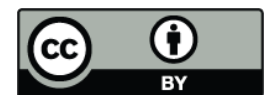

Correspondence to: J. G. Murphy

(jmurphy@chem.utoronto.ca)

\section{Introduction}

Atmospheric ammonia $\left(\mathrm{NH}_{3}\right)$ plays an important role in atmospheric processes and biogeochemical cycles. Ammonia readily neutralizes acidic compounds, reacting preferentially with sulphuric acid $\left(\mathrm{H}_{2} \mathrm{SO}_{4}\right)$ to form non-volatile aerosol species ammonium bisulfate $\left(\mathrm{NH}_{4} \mathrm{HSO}_{4}\right)$, letovicite $\left[\left(\mathrm{NH}_{4}\right)_{3} \mathrm{H}\left(\mathrm{SO}_{4}\right)_{2}\right]$ or fully neutralized ammonium sulfate $\left[\left(\mathrm{NH}_{4}\right)_{2} \mathrm{SO}_{4}\right]$ (Finlayson-Pitts and Pitts, 1999). Any additional $\mathrm{NH}_{3}$ is then available to take part in gas-particle partitioning with other atmospheric acids to form semi-volatile salts. In the case of ammonium nitrate $\left(\mathrm{NH}_{4} \mathrm{NO}_{3}\right)$, this equilibrium is strongly dependent on temperature and relative humidity, where colder, more humid conditions will shift the equilibrium to the particle phase (Stelson and Seinfeld, 1982). Ammonia is thus an important precursor to fine particulate matter $\left(\mathrm{PM}_{2.5}\right)$, the latter having repercussions with respect to human health (Pope et al., 2002) and to radiative budgets (IPCC, 2007). Fine particulate ammonium also has a longer atmospheric lifetime than gaseous $\mathrm{NH}_{3}$ and can therefore be transported and deposited further downwind (Makar et al., 2009). Deposition of $\mathrm{NH}_{3}$ and $\mathrm{NH}_{4}^{+}$to the Earth's surface can fertilize nitrogen-limited ecosystems, and have detrimental effects such as eutrophication, soil acidification, and biodiversity loss in sensitive ecosystems (Fangmeier et al., 1994; Bobbink et al., 1998; Galloway et al., 2003; Krupa, 2003).

Unlike other anthropogenic pollutants, for example sulphur dioxide $\left(\mathrm{SO}_{2}\right)$ and nitrogen oxides $\left(\mathrm{NO}_{\mathrm{x}}\right)$, the dominant emissions for ammonia are area wide-sources (Erisman et al., 2008; US E.P.A., 2009; Makar et al., 2009), and are subject to large uncertainty. In Canada, the majority of these emissions are agricultural in origin, such as from the application of fertilizer and volatilization of animal wastes, with lesser impacts from light-duty gasoline vehicles and chemical industries (Environment Canada, 2010). Total Canadian

Published by Copernicus Publications on behalf of the European Geosciences Union. 
anthropogenic sources, including agriculture, are on the scale of 500000 tonnes per year whereas natural sources such as forest fires are estimated at 5000 tonnes per year (NPRI, 2010). Because of its contribution to fine aerosol mass loading, modeling efforts have investigated the relative effectiveness of ammonia emission reductions in curtailing $\mathrm{PM}_{2.5}$ formation (Pinder et al., 2007; Tsimpidi et al., 2007; Pinder et al., 2008; Makar et al., 2009). Controls were found to be most effective in the winter when lower ammonia resulted in significant decreases in the mass loadings of ammonium nitrate relative to the base case.

Emission reductions may be more challenging to implement for $\mathrm{NH}_{3}$ than for $\mathrm{SO}_{2}$ and $\mathrm{NO}_{\mathrm{x}}$ due to the nature and distribution of its sources. Additionally, area-wide emissions depend on both past and present land use. There is substantial evidence that over certain land types both emission and deposition of ammonia can occur depending on the ambient mixing ratios (eg. Farquhar et al., 1980; Sutton et al., 1993; Sutton et al., 1995; Asman et al., 1998; Nemitz et al., 2001). This bi-directional flux implies a compensation point: an atmospheric mixing ratio below which emission is observed and above which deposition is observed. Studies have shown that the compensation point is dependent on surface temperature and on the ratio $\Gamma=\left[\mathrm{NH}_{4}^{+}\right] /\left[\mathrm{H}^{+}\right]$in soil and vegetation. This ratio is dependent on the accumulation of nitrogen from past fertilization (Massad et al., 2010). The deposition rate is also known to be dependent on the surface type and on the co-deposition of acidic species such as $\mathrm{SO}_{2}, \mathrm{HNO}_{3}$ and $\mathrm{HCl}$ (Erisman and Wyers, 1993; Flechard et al., 1999). Recent attempts to parameterize the bi-directional flux of ammonia for inclusion in models have suggested improved model-measurement agreement (Wu et al., 2009; Kruit et al., 2010; Massad et al., 2010; Zhang et al., 2010). In addition to emission and deposition to the surface, condensation to and volatilization from particles plays an important role in determining the gas phase mixing ratio of ammonia. The interactions between the surface-atmosphere exchange with gas-particle partitioning of ammonia have been investigated in several studies (Brost et al., 1988; Harrison et al., 1989; Kramm and Dlugi, 1994). Wolff et al. (2010), showed that the timescale of surface fluxes is similar to the timescale of ammonium nitrate gas-particle partitioning.

Because of the high levels of uncertainty in the processes that govern the abundance of ammonia in the atmosphere, high time resolution measurements of ammonia are needed. Whitehead (2007), Nowak (2006) and Li (2006) studied the $\mathrm{NH}_{3}$ mixing ratios in urban environments and suggested ammonia emissions from traffic as a major source. Other studies have investigated the surface exchange of ammonia over crops and grassland (Walker et al., 2006; Kruit et al., 2007; Sutton et al., 2009; Bash et al., 2010). A few studies have made simultaneous high time resolution measurements of ammonia and particulate ammonium in recent years $(\mathrm{Ne}-$ mitz et al., 2004; Trebs et al., 2004; Nowak et al., 2010; Schaap et al., 2010). Nowak et al. (2006) compared mea- surements of ammonia made by a chemical ionization mass spectrometer to predictions from CMAQ, and found significant underpredictions from the model in the afternoon. Using the thermodynamic model ISORROPIA (Nenes et al., 1998) constrained by measurements of the chemical composition of fine particulate matter made by a particle into liquid sampler, it was determined that the thermodynamic partitioning was well-represented. The model underestimate of ammonia at midday led the authors to hypothesize that an additional light- or temperature-dependent source of ammonia was missing from the model.

The Border Air Quality and Meteorology Study (BAQSMet), which took place in southwestern Ontario in the summer of 2007, offered the opportunity to make observations in a region impacted by regional transport of aerosol and local emissions of ammonia. A suite of instrumentation, including ammonia and aerosol measurements, was deployed at the Harrow supersite to elucidate the primary and secondary sources and composition of $\mathrm{PM}_{2.5}$ in this region. The field study was a collaborative effort between universities and government scientists with research activities that included measurements from several platforms, and modeling support from Environment Canada's regional air quality model AURAMS (A Unified Regional Air-quality Modelling System). In this paper, we investigate the measurements and modeling associated with gas phase ammonia and particulate ammonium in terms of gas-particle partitioning and the surfaceatmosphere exchange of ammonia.

\section{Experimental methods}

\subsection{Site description}

Measurements were made at the Harrow ground site $\left(42^{\circ} 2^{\prime} 0^{\prime \prime} \mathrm{N}, 82^{\circ} 55^{\prime} 0^{\prime \prime} \mathrm{W}\right.$, elevation $\left.173 \mathrm{~m}\right)$, one of three BAQS-Met supersites. The site is situated in an agricultural area in southwestern Ontario, Canada, approximately $5 \mathrm{~km}$ north of the shoreline of Lake Erie and $30 \mathrm{~km}$ south of Windsor, ON. The surrounding area is used to grow soybeans, corn, grapes, apples and tomatoes. The area around Harrow is impacted by long range transport of $\mathrm{PM}_{2.5}$ and its precursors from the United States, especially areas in Ohio, Indiana and Illinois to the south and from Michigan to the northwest. The site is also impacted by urban and suburban emissions of pollutants from Windsor and Detroit and from local agricultural emissions. Harrow was often subject to lake breezes delivering onshore flow from Lake Erie in the middle of the day, hence our site provided information on the gas and particle chemistry taking place over the lake at night.

\subsection{QC-TILDAS}

Gas-phase measurements of ammonia were made using a Quantum Cascade Tunable Infrared Laser Differential Absorption Spectrometer (QC-TILDAS), developed by 
Aerodyne Research Inc. (Billerica, MA) and described in detail in Ellis et al. (2010). The QC-TILDAS monitors the $\mathrm{NH}_{3}$ absorption spectrum at $967 \mathrm{~cm}^{-1}$ using a thermoelectrically cooled, pulsed quantum cascade (QC) laser (Alpes Lasers, Neuchatel, Switzerland) which provides higher stability and increased power output over traditional diode lasers (McManus et al., 2002). The laser beam is directed into an astigmatic Herriot type multiple pass absorption cell $(0.5 \mathrm{~L}, 76 \mathrm{~m}$ effective pass length) coated with a hydrophobic coating in an effort to reduce the interaction of $\mathrm{NH}_{3}$ with cell walls. A reference cell containing ethylene $\left(\mathrm{C}_{2} \mathrm{H}_{4}\right)$, a less surface reactive gas that contains an absorption line near that of $\mathrm{NH}_{3}$ is used for absorption-line lock. The signal and reference paths are separated temporally by $250 \mathrm{~ns}$ and focused on the same thermoelectrically cooled Mercury Cadmium Telluride (HgCdTe) infrared detector (Vigo Systems, Poland).

The laser control, spectral retrieval and mixing ratio calculations are managed by the software package TDLWintel, developed by Aerodyne Research Inc. The laser is scanned across the full $\mathrm{NH}_{3}$ transition and the resulting spectrum is fit by convolving the laser line shape with a calculated absorption line shape based on the HITRAN (high-resolution transmission) molecular absorption database and the measured pressure, temperature and path length of the optical cell (Herndon et al., 2007). Although TDLWintel calculates absolute mixing ratios, calibration is highly recommended when measuring surface reactive gases such as ammonia. The software allows for automatic user defined additions of calibration gas and background gas through the use of two solenoid valves. Further description of the QC-TILDAS design and data acquisition system can be found in Nelson et al. (2004).

The QC-TILDAS uses a $10 \mathrm{~cm}$, heated (to $40 \pm 2{ }^{\circ} \mathrm{C}$ ) quartz inlet which is internally coated with a hydrophobic fluorinated silane coating to limit condensation of water and interaction of $\mathrm{NH}_{3}$ with inlet surfaces. A critical orifice is used to achieve a flow of $\sim 9 \mathrm{~L} \mathrm{~min}^{-1}$ (measured upstream at $101.3 \mathrm{kPa}$ and $298 \mathrm{~K}$ ) and maintain the pressure in the sampling lines and optical cell between $5.3-8 \mathrm{kPa}$ in order to reduce absorption line broadening (Whitehead et al., 2008). The flow is split after the critical orifice, with $90 \%$ of the flow making a sharp turn and being pulled through the optical cell. The other $10 \%$ is pulled directly to the pump, relying on inertia to remove particles larger than $300 \mathrm{~nm}$ and eliminating the use of a particle filter, which may cause interferences from ammonium (Gras, 1984; Cheng and Tsai, 1997; Chow et al., 1998). The inlet also includes two ports for the introduction of calibration gas and background gas, designed so that these flows encounter the inlet in the same way as ambient sampling. During BAQS-Met, the inlet was mounted on top of the measurement trailer, at a height of $3 \mathrm{~m}$ above the ground, and connected to the QC-TILDAS via a $2.5 \mathrm{~m}$ long, $3 / 8$ inch PFA sample tube. Laboratory tests demonstrate the ability to restrict the majority ( $>90 \%$ ) of the bi-exponential $\mathrm{NH}_{3}$ time response to less than $0.4 \mathrm{~s}$ when using the quartz inlet in conjunction with a heated line. The ammonia time response is thus sufficient for data acquisition at $1 \mathrm{~Hz}$, with a detection limit of $0.6 \mathrm{ppb}$. As the instrument is mostly dominated by random noise, averaging the data to $5 \mathrm{~min}$ brings the detection limit to $42 \mathrm{ppt}$ with a precision of $14 \mathrm{ppt}$.

\section{$2.3 \quad$ AIM-IC}

The inorganic composition of $\mathrm{PM}_{2.5}$ was measured by Ambient Ion Monitor Ion Chromatography (AIM-IC). The AIMIC is capable of continuous, hourly online measurements of the inorganic constituents of $\mathrm{PM}_{2.5}\left(\mathrm{SO}_{4}^{2-}, \mathrm{NO}_{3}^{-}, \mathrm{NH}_{4}^{+}, \mathrm{Cl}^{-}\right.$, $\mathrm{NO}_{2}^{-}, \mathrm{Na}^{+}, \mathrm{K}^{+}, \mathrm{Ca}^{2+}$, and $\mathrm{Mg}^{2+}$ ) and some precursor gases $\left(\mathrm{HNO}_{3}, \mathrm{NH}_{3}, \mathrm{HCl}, \mathrm{SO}_{2}\right.$ and $\left.\mathrm{HONO}\right)$ with limits of detection as low as $0.1 \mu \mathrm{g} \mathrm{m}^{-3}$. The instrument consists of an AIM 9000D air sampler (URG Corp., Chapel Hill, NC) fitted with a $2.5 \mu \mathrm{m}$ cyclone for particle size-selection, a constantlygenerated wet parallel-plate denuder for the collection of gases, a particle supersaturation chamber and two ICS-2000 ion chromatographs (Dionex Corp., Sunnyvale, CA). The anion IC was equipped with a potassium hydroxide eluent generator cartridge (KOH EGC II), TAC-ULP1 $(4 \mathrm{~mm})$ concentrator column, IonPac AG and AS19 guard and analytical columns, ASRS ULTRA II(4-mm) suppressor and CD25A conductivity detector operated at $30^{\circ} \mathrm{C}$. Anion chromatographic runs were performed isocratically with $20 \mathrm{mM} \mathrm{KOH}$ at a flow of $1 \mathrm{~mL} \mathrm{~min}{ }^{-1}$. The cation IC was equipped with a methanesulphonic acid eluent generator cartridge (MSA EGC II), TCC-ULP1 (4 mm) concentrator column, IonPac CG and CS12A guard and analytical columns, CSRS ULTRA II(4-mm) suppressor and CD25A conductivity detector operated at $30^{\circ} \mathrm{C}$. Cation runs were performed isocratically with $20 \mathrm{mM}$ MSA at a flow of $1 \mathrm{~mL} \mathrm{~min}{ }^{-1}$. Ambient air was sampled at $3 \mathrm{~L} \mathrm{~min}-1$ for the first $55 \mathrm{~min}$ of each hour and hourly averages of all species were reported in $\mu \mathrm{g} \mathrm{m}^{-3}$ via Chromeleon 6.8 and URGAIM software. An off-line calibration of the AIM-IC was performed in-field by directly injecting multiple ion standards into each IC, providing accuracy of better than $15 \%$. The inlet was co-located with the QC-TILDAS inlet, approximately $3 \mathrm{~m}$ above the ground. Following the campaign, it was determined that the sampling inlet $(2 \mathrm{~m}, 1 / 2$ inch OD Teflon-coated aluminum tube (URG, Corp.) breaching a 4 inch diameter PVC pipe pulling a bypass flow of $\sim 20 \mathrm{~L} \mathrm{~min}^{-1}$ ) was not appropriate for the quantitative sampling of gases, especially soluble ones such as $\mathrm{HNO}_{3}$ and $\mathrm{NH}_{3}$, so only the $\mathrm{PM}_{2.5}$ measurements are used in this analysis. Based on comparisons with the AMS instrument at our site, it does not appear that there were significant particles losses resulting from electrostatic effects in the AIM-IC inlet.

\subsection{Air quality modeling}

Ground-based measurements were supported in real time by Environment Canada's AURAMS (A Unified Regional 
Air-quality Modelling System) which consists of three main components: (a) a prognostic meteorological model, GEM: Global Environmental Multiscale model, (Cote et al., 1998); (b) an emissions processing system, SMOKE: Sparse Matrix Operator Kernel Emissions, (Houyoux et al., 2000; CEP, 2003) and (c) an off-line regional chemical transport model, the AURAMS Chemical Transport Model (cf. Gong et al., 2006; Stroud et al., 2008; Cho et al., 2009; Makar et al., 2009; Smyth et al., 2009).

Following the conclusion of the BAQS-Met measurement campaign, AURAMSv1.4.0 was configured to run with three levels of nesting: a $2.5 \mathrm{~km}$ high resolution local domain nested within a $15 \mathrm{~km}$ regional domain, nested within a $42 \mathrm{~km}$ North American domain. Further details on the model setup for these simulations and a more detailed description of the model are given in Makar et al. (2010), this issue. Output of mixing ratios and mass loadings from the $2.5 \mathrm{~km}$ resolution domain at the surface for the Harrow grid-square was used to compare to measurements of ammonia and particulate ammonium, sulfate, and nitrate. Aerosol partitioning is calculated in AURAMS as a bulk calculation across all particle sizes using HETV (Makar et al., 2003), a vectorized form of ISORROPIA. AURAMS uses a speciated sectional approach to describe the aerosol size distribution: mass from the first 8 bins, encompassing the 0 to $2.5 \mu \mathrm{m}$ range, were used to calculate the $\mathrm{PM}_{2.5}$ mass loadings of particulate matter for comparison to the size-selection used by the AIM-IC observations.

In order to obtain outputs of mixing ratios and mass loadings of atmospheric species, AURAMS solves a set of complex differential equations that describe the rate of change of each model species. The solution is split into different components (operators) which are solved in sequence, with the solution from each operator becoming the initial concentrations for the next operator in the sequence (Makar et al., 2010). AURAMS can be configured to track the change in mass of model species of interest for each operator for each time step. Using this mass-tracking, it is possible to obtain important model information on gas-particle partitioning, advection, vertical exchange and diffusion of a species of interest.

\section{Results and discussion}

\subsection{Ammonia mixing ratio analysis}

Near continuous measurements of ammonia were acquired using the QC-TILDAS at $1 \mathrm{~Hz}$ between June 20 to July 13 at the Harrow supersite. The ammonia mixing ratios were averaged to $5 \mathrm{~min}$ for viewing simplicity and are displayed in Fig. 1. We observed an average of approximately $2.5 \mathrm{ppb}$ throughout the measurement campaign, with shortlived spikes of up to $30 \mathrm{ppb}$ on the order of minutes and over $50 \mathrm{ppb}$ on the order of seconds. The majority of these

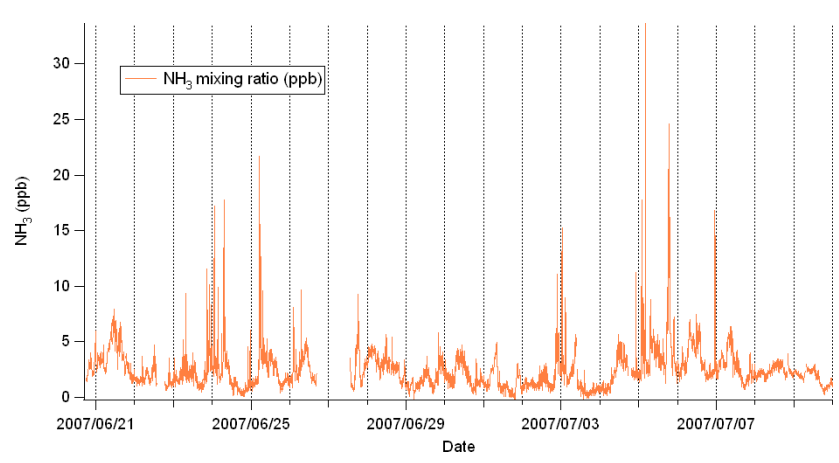

Fig. 1. Five minute averaged ammonia mixing ratios during BAQSMet fluctuated around $2.5 \mathrm{ppb}$, with higher, shorter spikes up to $30 \mathrm{ppb}$ mostly occurring during night-time.

spikes occurred at night, which we attribute to local emissions, such as from traffic, into a shallow nocturnal boundary layer. It is known that ammonia can be formed from the incomplete reduction of $\mathrm{NO}_{\mathrm{x}}$ in light-duty automobiles equipped with three-way catalytic converters (Kean et al., 2009; Livingston et al., 2009). We investigated the time series of other traffic-related species such as benzene, toluene, nitrogen oxides $\left(\mathrm{NO}_{\mathrm{x}}\right)$ and carbon monoxide $(\mathrm{CO})$ but could not exactly match ammonia spikes to any of these species on the order of minutes. Nights on which we observed high spikes in ammonia coincided with high and variable mixing ratios of these other traffic-related species. The offset between these species of several minutes may be due to the different location of instrument inlets, different data acquisition times and different types of automobile combustion engines. For example, ammonia is mostly emitted from light-duty vehicles (NPRI, 2010) while $\mathrm{NO}_{\mathrm{x}}$ is generally associated with heavy-duty diesel vehicles such as trucks. Li et al. (2006) also observed that not all automobiles emit ammonia under on-road driving conditions, and Whitehead et al. (2007) did not see a significant correlation between $\mathrm{NO}_{\mathrm{x}}$ and $\mathrm{NH}_{3}$ in the summer. Meteorological data were examined to further investigate possible sources of the ammonia spikes.

Polar plots of the dependence of ammonia mixing ratios on wind direction are shown in Fig. 2. These plots display 5 min averaged ammonia data on the radial axis coloured as a function of (a) wind speed, (b) temperature and (c) relative humidity. The polar plots indicate sporadic high mixing ratios of ammonia originate in the east and the southwest of the measurement site, while binning the data into 10-degree intervals (Fig. 2d) show that the largest regional source was to the northwest. This enhancement in the northwest may be due to a local unidentified agricultural or industrial source or transport from the Windsor/Detroit area, which is approximately $30 \mathrm{~km}$ away from Harrow. Although $\mathrm{NH}_{3}$ has a high deposition velocity and is expected to be lost quickly to the surface, transport of $\mathrm{NH}_{3}$ over such distances has been previously observed (Sakurai et al., 2003). In the eastern quadrant, 

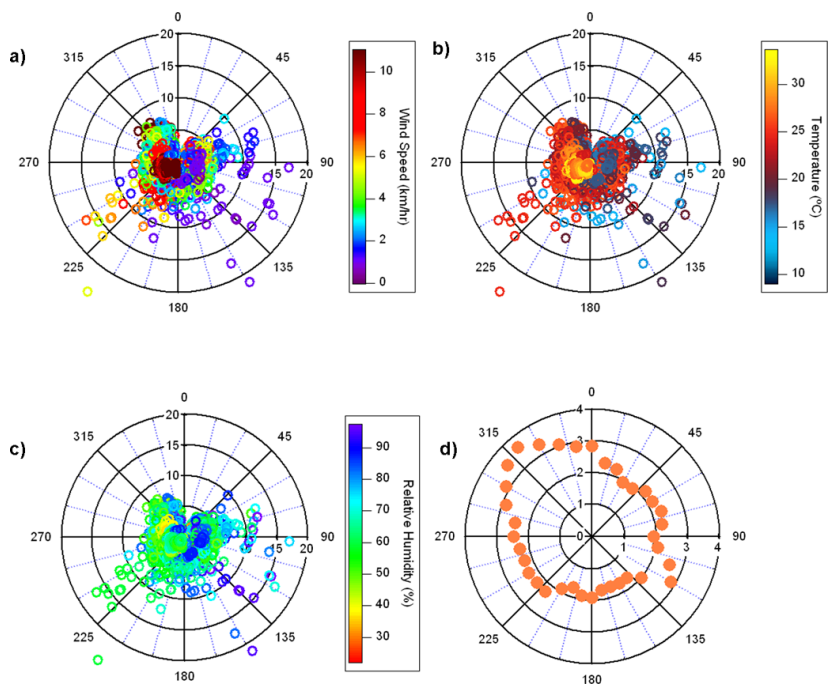

Fig. 2. Wind direction polar plots of ammonia mixing ratios (ppb) coloured as a function of (a) wind speed, (b) temperature and (c) relative humidity. Panel (d) shows the average of all data in each 10 degree bin and indicates a dominant source in the northwest.

we observe many instances when the mixing ratio was $10 \mathrm{ppb}$ or higher, characterized by low wind speeds, low temperatures $\left(\sim 15^{\circ} \mathrm{C}\right)$ and high relative humidity $(>75 \%)$, which are consistent with night-time conditions. A local road approximately $40 \mathrm{~m}$ away and directly east of the measurement site may be the source of these night-time ammonia spikes. We have eyewitness evidence that street racing was occurring on some nights, and Livingston et al. (2009) stated that aggressive driving is likely to lead to higher ammonia emissions. A secondary regime with frequent high ammonia events exists in the southwest, with higher wind speeds, relative humidity between $50-60 \%$ and high temperatures of approximately $25^{\circ} \mathrm{C}$, indicating daytime flow. Southwest of the measurement site was a field managed by Agriculture and Agrifood Canada, growing mostly soybean and corn crops. On some days, employees were seen turning the soil and working the field. This activity was not logged, however, and we cannot establish whether it had any effect on the ammonia concentrations. As each point on the polar plot is a $5 \mathrm{~min}$ averaged data point, the short-lived but high ammonia mixing ratios events may mask any indication of a dominant source.

There is no change in the average ammonia mixing ratio when air is coming from the south in the direction of Lake Erie. One would assume that an air mass passing over a water body would become depleted of ammonia, because the effective Henry's Law constant of ammonia is very high. On the other hand, the deposition velocity of surface reactive gases such as ammonia is lower over water than over land due to less vigorous vertical mixing over water, possibly extending the lifetime of ammonia against deposition (Seinfeld and Pandis, 2006). When southerly air masses, consistent with onshore flow, impacted Harrow, lower ammonia mixing

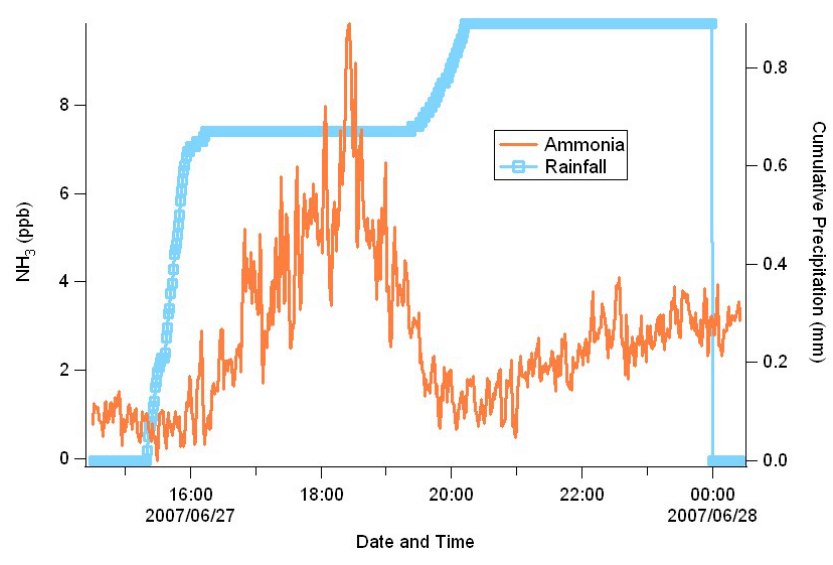

Fig. 3. One example of a precipitation event that was followed by a significant increase in ammonia mixing ratio.

ratios were not observed. We investigated the ammonia time series for each day of the study looking for an increase in relative humidity and shift in wind direction to southerly that would indicate a lake breeze. Because lake breeze passages consistently occurred in the middle of the day, when emissions of ammonia are expected to be the highest, it is also possible that the volatilization of ammonia from the agricultural fields in the $5 \mathrm{~km}$ between the lakeshore and the measurement site was sufficient to replenish the ammonia mixing ratio in the air that had been over the lake. However, we do not have any evidence that the ammonia mixing ratios at the edge of the lake were lower (or different) than at the measurement site.

Four significant precipitation events were identified from the meteorological data. During all four precipitation events, the ammonia mixing ratios dropped between 1-2 ppb and remained low for the duration of the rain storm. It is known that ammonia is effectively scavenged by raindrops and can decrease during rainfall (Nowak et al., 2006). We were unable to fit for the scavenging coefficient due to both short duration of the rainfall and the low absolute changes in ammonia mixing ratios during some of the precipitation events. After the rain ceased, significant increases in mixing ratios were observed as demonstrated in Fig. 3. From a regional analysis which identified changes in air mass at the site, there were no air mass changes during those times. The increase in ammonia mixing ratios after the rain may be from increased microbial processes in soil and vegetation that can release ammonia. Roelle and Aneja (2002) observed soil surface emissions of $\mathrm{NH}_{3}$ to be enhanced by rainfall in a North Carolina coastal plain. Similarly, McCalley and Sparks (2008) observed an immediate, large pulse of $\mathrm{NH}_{3}$ after rainfall over dry, desert soil. In that study, emissions were found to be influenced by soil conditions and nutrient availability, information which is not available from the BAQS-Met campaign. 


\subsection{Diurnal behaviour}

For the remainder of the paper, we use hourly averages of ammonia observations, with the short duration spikes removed, to match the acquisition time of the AIM-IC system. We investigated the time of day behaviour for ammonia, which is plotted in Fig. 4 along with particulate $\mathrm{NH}_{4}^{+}$, $\mathrm{SO}_{4}^{2-}$ and $\mathrm{NO}_{3}^{-}$(in mole equivalents). For ammonia, there is an average mass loading of $1.5 \mu \mathrm{g} \mathrm{m}^{-3}$ with a sharp morning rise and a slow decrease in concentration in the afternoon. The morning rise between 06:00 and 07:00 could be attributed to one of several reasons, including evaporation of dew, volatilization of particulate ammonium, emission from plant stomata, or mixing down of ammonia from the residual layer. We consider each of these hypotheses in turn. When the sun comes up and heats the surface, the evaporation of dew could release ammonia trapped in liquid water condensed on surfaces. Kruit et al. (2007) also observed a morning peak in concentrations which coincided with a decrease in leaf wetness. The BAQS-Met study did not include measurements of leaf wetness, but the measured relative humidity did exceed $95 \%$ on several nights during the measurement campaign. Figure 4 illustrates that the relative humidity and temperature did not change significantly during the hours of 06:00-07:00, but increased later in the morning. If evaporation of dew is the reason for the $\mathrm{NH}_{3}$ increase, we would expect it to be coincident with a large increase in temperature, which can heat the surface enough to allow for evaporation. It is possible that the temperature of the soil increases slightly earlier than the temperature of the atmosphere at $2 \mathrm{~m}$ (the height of our RH/T probe), but we have no measurements of the soil temperature. While the rate of increase of $\mathrm{NH}_{3}$ in the morning was not substantially higher following nights with formation of dew, Flechard et al. (1999) states that significant amounts of ammonia can be stored in leaf water layers formed at RH below $100 \%$. Without measurements of surface wetness and surface temperature, we cannot conclusively confirm or rule out volatilization from the surface.

Because the largest increase in ammonia also precedes the large changes in atmospheric relative humidity and temperature, and because the particulate ammonium is flat during that time, volatilization of ammonium is ruled out as a significant contribution to the morning rise in ammonia. Plant and/or soil processes may be a more likely reason for this morning rise, as observed by Bash et al. (2010) in a corn field. The local sunrise in Harrow at this time of year was around 05:45, and as an immediate response, plant stomata open for photosynthesis. During this time, release of ammonia from the apoplastic fluid can occur through the stomata, which may lead to an increase in concentration at this time. This increase would be more prominent if the emission is occurring into a shallow nocturnal boundary layer. On the other hand, the morning rise may also be due to the

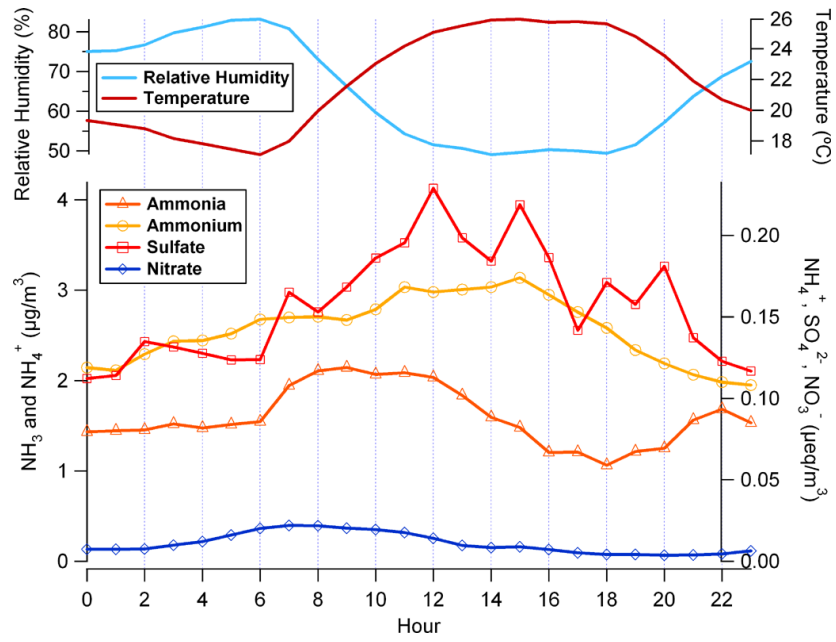

Fig. 4. Average diurnal cycles of relative humidity and temperature with ammonia and ammonium concentrations. Ammonia concentrations display a rise in the early morning hours, followed by decrease in the afternoon. Mole equivalents of ammonium, sulfate and nitrate are plotted on the right axis and show the relative importance of sulfate and nitrate in the aerosol.

breakup of the nocturnal boundary layer. As the surface heats up and vertical mixing begins, the downward mixing of the residual layer, which may contain relatively higher ammonia, could lead to a surface increase. This effect was also observed by Walker et al. (2006) who attributed an early morning increase in $\mathrm{NH}_{3}$ surface concentrations to a deposition flux. At Harrow, our observations of early morning concentration changes rule out a significant contribution from particle volatilization, but are not sufficient to identify whether the main cause of the morning increase is surface emissions or mixing down from above. In the future, simultaneous flux measurements would be ideal to elucidate the contributing processes.

\subsection{Gas-particle partitioning}

The diurnal changes in aerosol species and their gaseous precursors are controlled by emission and deposition processes, horizontal and vertical transport and gas-particle partitioning. Between 10:00 and 15:00, we observe a decrease in measured ammonia corresponding in magnitude to an increase in ammonium, which coincides with high mass loadings of sulfate at the site. This decrease in gas phase ammonia is likely the result of uptake onto aerosols to form $\left(\mathrm{NH}_{4}\right)_{2} \mathrm{SO}_{4}$. Figure 4 shows that on average the aerosol was mostly neutral with some instances of acidic aerosol in the afternoons. The equivalents of sulfate only exceeded the equivalents of ammonium on afternoons when the sulfate mass loadings were very high $\left(>20 \mu \mathrm{g} \mathrm{m}^{-3}\right)$. The nitrate is an insignificant constituent of the aerosol, consistent with the analysis of Markovic et al. (2010) who used 

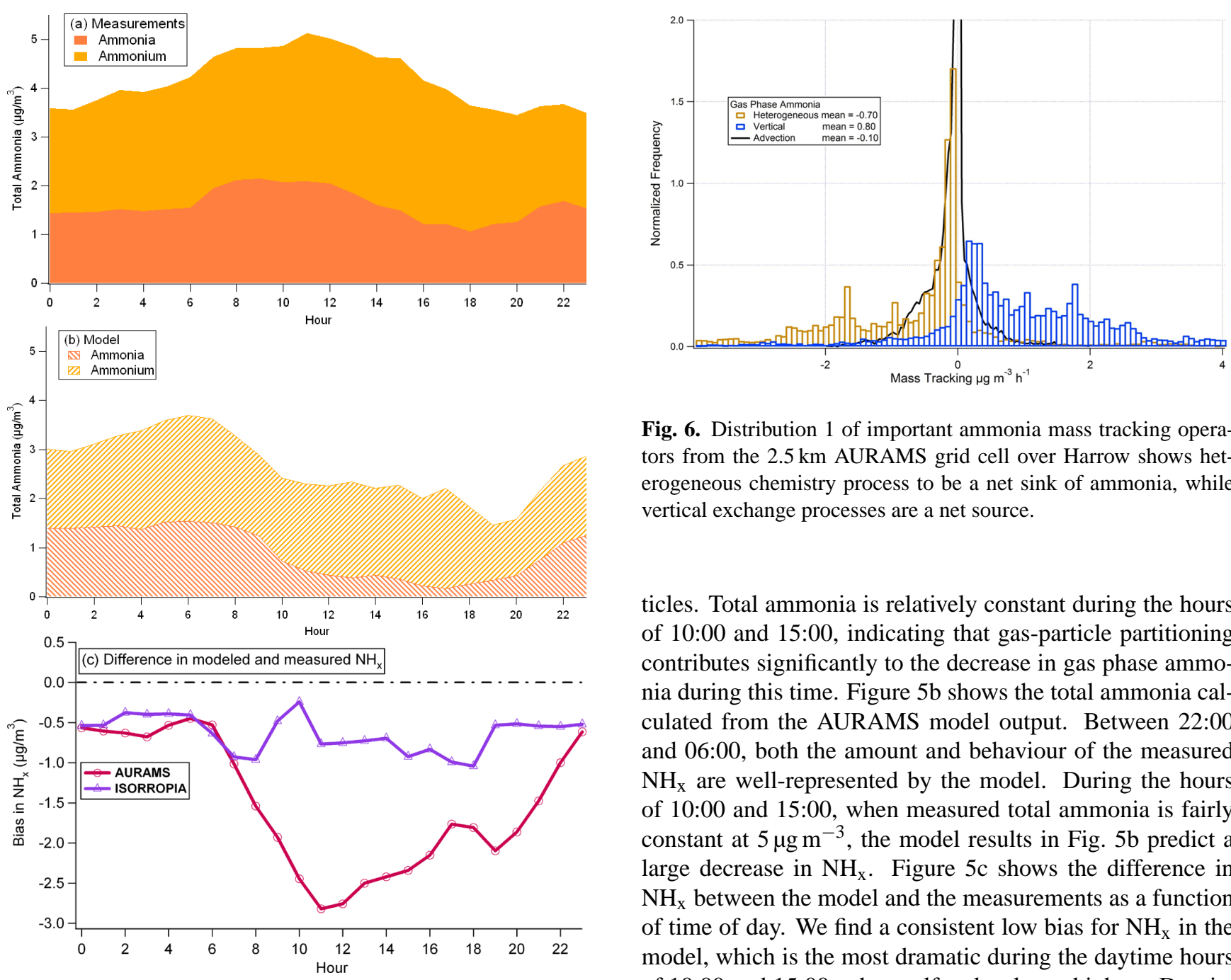

Fig. 6. Distribution 1 of important ammonia mass tracking operators from the $2.5 \mathrm{~km}$ AURAMS grid cell over Harrow shows heterogeneous chemistry process to be a net sink of ammonia, while vertical exchange processes are a net source.

ticles. Total ammonia is relatively constant during the hours of 10:00 and 15:00, indicating that gas-particle partitioning contributes significantly to the decrease in gas phase ammonia during this time. Figure $5 \mathrm{~b}$ shows the total ammonia calculated from the AURAMS model output. Between 22:00 and 06:00, both the amount and behaviour of the measured $\mathrm{NH}_{\mathrm{x}}$ are well-represented by the model. During the hours of 10:00 and 15:00, when measured total ammonia is fairly constant at $5 \mu \mathrm{g} \mathrm{m}^{-3}$, the model results in Fig. $5 \mathrm{~b}$ predict a large decrease in $\mathrm{NH}_{\mathrm{x}}$. Figure $5 \mathrm{c}$ shows the difference in $\mathrm{NH}_{\mathrm{x}}$ between the model and the measurements as a function of time of day. We find a consistent low bias for $\mathrm{NH}_{\mathrm{x}}$ in the model, which is the most dramatic during the daytime hours of 10:00 and 15:00, when sulfate levels are highest. Despite predicting an appropriate range of midday sulfate levels, the

Fig. 5. Stacked plots of the components of total ammonia (top of the trace) for (a) measurements and (b) model. The difference between the modeled and measured $\mathrm{NHx}$ is shown in (c) and indicates that the model is biased low in $\mathrm{NH}_{\mathrm{x}}$.

AMS data from the same site and saw that nitrate was only important in the early morning hours. To investigate gasparticle conversion further we looked at the total ammonia $\left(\mathrm{NH}_{\mathrm{x}}\right)$, which is the sum of ammonia and ammonium, shown as a stacked plot in Fig. 5a. At equilibrium, a decrease in $\mathrm{NH}_{3}$ would result in an increase in $\mathrm{NH}_{4}^{+}$, and a plot of $\mathrm{NH}_{\mathrm{x}}$ would be constant assuming no additional sources or sinks. Thus, the effect of gas-particle partitioning is removed in plots of $\mathrm{NH}_{\mathrm{x}}$, and the diurnal variability is controlled only by transport and vertical exchange. Between the hours of 10:00-15:00, $\mathrm{NH}_{3}$ decreased by $30 \%$ while $\mathrm{NH}_{\mathrm{x}}$ decreased by only $10 \%$. We observe higher values of $\mathrm{NH}_{\mathrm{x}}$ during the daytime hours, likely because the emissions of ammonia are more significant due to higher temperatures or because of the transport to the site of ammonium sulfate parmodel is biased low for ammonium because it predicts much lower $\mathrm{NH}_{\mathrm{x}}$, which is insufficient to neutralize the aerosol. Repartitioning the observations using the ISORROPIA thermodynamic model (Nenes et al., 1998) results in an overall negative bias in $\mathrm{NH}_{\mathrm{x}}$, but without the large discrepancy AURAMS exhibits in the afternoon. This indicates that incorrect gas-particle partitioning is not responsible for the large bias in the model during the day, pointing to parameterizations of surface exchange or transport as the main causes for discrepancy.

Figure 6 displays the distribution of important ammonia mass tracking operators extracted from AURAMS in the Harrow grid square for the lowest $6.89 \mathrm{~m}$ above the surface. The heterogeneous operator describes inorganic heterogeneous and aqueous phase chemistry (i.e. gas-particle partitioning), the vertical exchange operator includes the net change associated with emissions, deposition and vertical diffusion of ammonia, and the advection term describes mass changes associated with total three-dimensional advective transport. On average, the model predicts heterogeneous chemistry as 


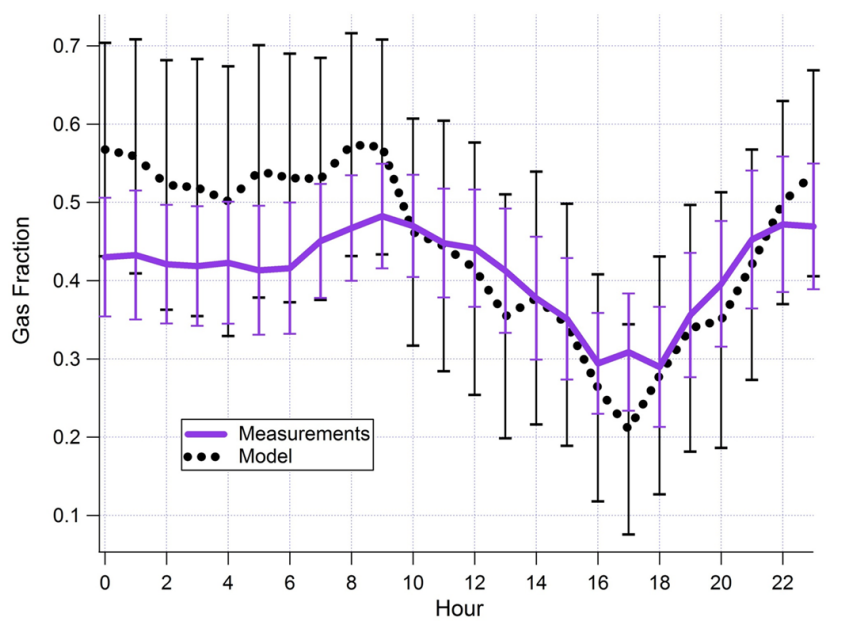

Fig. 7. Diurnal cycles of the measured and modeled gas fraction $\left(\mathrm{NH}_{3} / \mathrm{NH}_{\mathrm{X}}\right)$ with the error bars representing the $95 \%$ confidence interval.

a sink for ammonia, consistent with the existence of acidic particles in the model. The net vertical exchange term is on average positive, thus vertical exchange is usually a source of ammonia in the Harrow grid square, which is most likely due to emissions, rather than diffusion from above. The model considers advection to cause only small changes, and identifies vertical exchange and heterogeneous chemistry as the controlling factors for $\mathrm{NH}_{3}$. Because the model does a poor job of representing the observations of both $\mathrm{NH}_{3}$ and $\mathrm{NH}_{\mathrm{x}}$, the model's representation of the relative importance of these processes is not necessarily correct.

The ability of the model to accurately describe the gasparticle partitioning of the measurements is further investigated by plotting the fraction of total ammonia in the gas phase in Fig. 7 (gas fraction $\equiv \mathrm{NH}_{3} / \mathrm{NH}_{\mathrm{x}}$ ). In the early morning, a higher fraction of ammonia is in the gas phase, while in the late morning to afternoon, the gas phase fraction decreases quickly. This is consistent with an early morning increase in gas phase ammonia concentrations from vertical transport or surface exchange, followed by gas-particle conversion in the afternoon. The model is biased slightly high at night, and low during the day, but appears to represent the overall diurnal cycle well, also suggesting that on average, gas-particle partitioning is not the cause of the differences noted in Fig. 5. The low bias during the day is the result of the model also being biased low in $\mathrm{NH}_{\mathrm{x}}$, pointing to issues with the surface-atmosphere exchange. Additionally, when the measured $\mathrm{NH}_{\mathrm{x}}$ is repartitioned offline using ISORROPIA and observed $\mathrm{SO}_{4}^{2-}$ and $\mathrm{NO}_{3}^{-}$, the modeled gas-particle partitioning matches the observations very well. With the elimination of inorganic heterogeneous chemistry as a cause for the differences, emission, deposition and vertical diffusion remain as possible causes. As these three terms are described by a single operator in AURAMS, we could not identify the

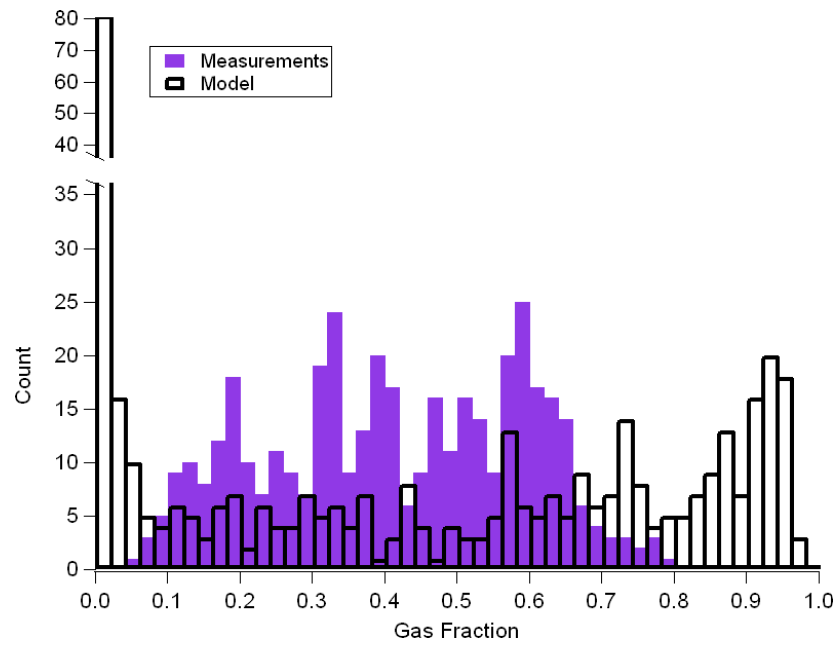

Fig. 8. Histogram of the measured and modelled gas fraction $\mathrm{NH}_{3} / \mathrm{NH}_{\mathrm{x}}$.

main cause of the discrepancy between the model and measurements.

The variability in the ammonia gas fraction predicted by the model, shown in the error bars, is much larger than observed. To better illustrate the extreme values in the model output, histograms of the observed and modelled gas fractions were calculated and displayed in Fig. 8. The observations are clustered in the middle of the histrogram, while the model tends to be bi-modal, with nearly all of the $\mathrm{NH}_{\mathrm{x}}$ predicted in the gas phase (gas fraction $>0.8$ ) or in the particle phase (gas fraction $<0.05$ ). In Fig. 9, the gas fraction correlates strongly with the sulfate levels in both measurements (a) and model (b). However, the measured gas fraction rarely drops below 0.1 even when sulfate levels exceed $10 \mu \mathrm{g} \mathrm{m}^{-3}$, and never rises above 0.8 , even when sulfate is less than $1 \mu \mathrm{g} \mathrm{m}^{-3}$. This implies some buffering process that is not represented in the model, which allows additional ammonia to enter the atmosphere in the presence of a large condensation sink that exists when there are high mass loadings of $\mathrm{SO}_{4}^{2-}$ present. On days with neutralized aerosol, the net uptake rate of ammonia is governed by the production rate of $\mathrm{H}_{2} \mathrm{SO}_{4}$. We calculated this using observed midday $\mathrm{SO}_{2}$ concentrations of $2 \mathrm{ppb}$, assuming $5 \times 10^{6} \mathrm{OH}$, and obtained a production rate at $298 \mathrm{~K}$ of $0.04 \mathrm{ppb} \mathrm{h}^{-1}$. Since two equivalents of ammonia are required to neutralize $\mathrm{H}_{2} \mathrm{SO}_{4}$, this results in $0.08 \mathrm{ppbh}^{-1}$ or $0.056 \mu \mathrm{g} \mathrm{m}^{-3} \mathrm{~h}^{-1}$ loss of $\mathrm{NH}_{3}$. This calculation is a lower limit as it does not account for heterogeneous production of $\mathrm{H}_{2} \mathrm{SO}_{4}$. The calculated production rate is significant compared to the rate of surface exchange $\left(0.3 \mu \mathrm{g} \mathrm{m}^{-3} \mathrm{~h}^{-1}\right)$ calculated by the model for afternoon conditions. This implies that even in cases with neutral aerosol a strong condensation sink in the atmosphere still exists and if this term were included in the model it would have an impact on the surface fluxes. 

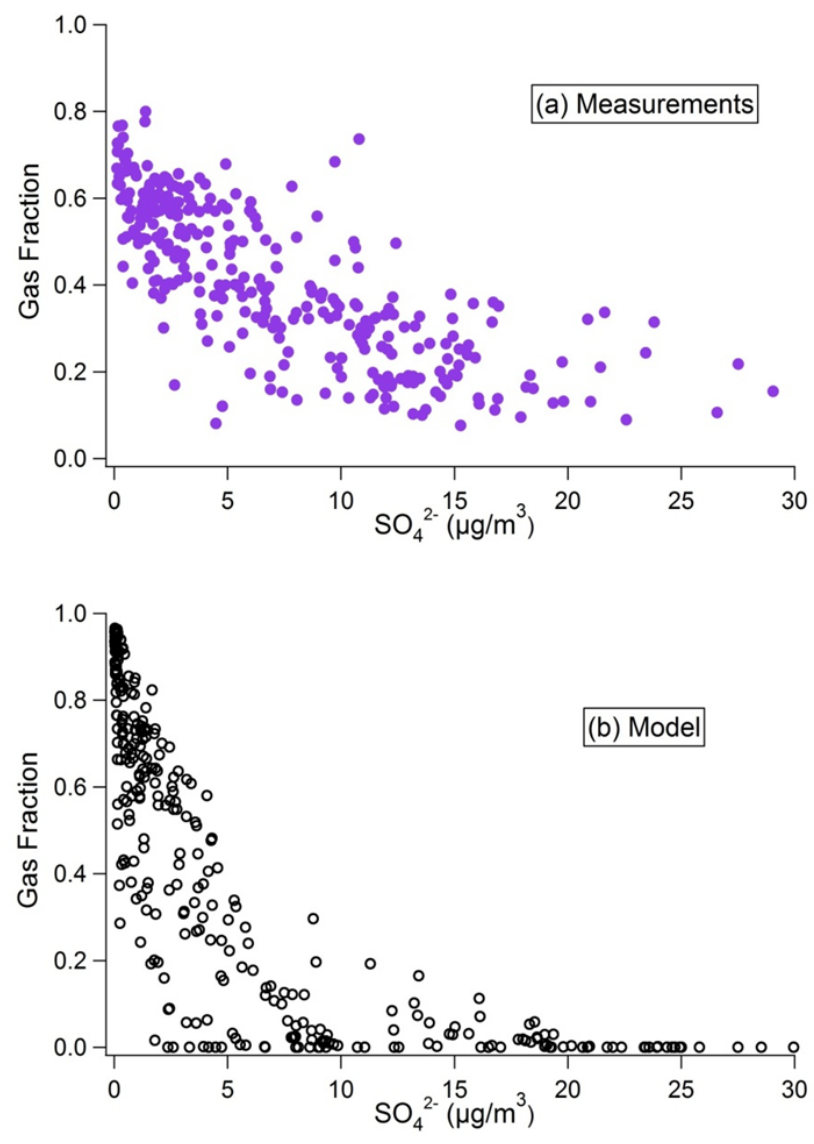

Fig. 9. Gas fraction of (a) measured and (b) modelled ammonia as a function of $\mathrm{PM}_{2.5}$ sulfate.

\subsection{Ammonia bi-directional flux}

Like most chemical transport models, AURAMS uses a thermodynamic model based on ISORROPIA (Makar et al., 2003) to solve for the equilibrium concentrations of ammonia and ammonium in each grid cell. When we used our observations as input to the offline version of the same thermodynamic model, ISORROPIA v2.1, the gas-particle partitioning matched the observations very closely, confirming that the assumption of equilibrium partitioning was valid. Thus we turn our attention to other processes in the model that can be responsible for the differing behaviour between model predictions and measurements evident in Fig. 8. The total ammonia predicted in each grid cell in the model is governed by the difference between emissions and deposition, and horizontal advection. According to the model, the contribution of three-dimensional advection was minimal for both $\mathrm{NH}_{3}$ and $\mathrm{NH}_{4}^{+}$except at low concentrations. Both the emission and dry deposition of $\mathrm{NH}_{4}^{+}$are negligible, so the dominant process driving variability of total ammonia in the boundary layer is the surface-atmosphere exchange of gaseous ammonia. For $\mathrm{NH}_{3}$, AURAMS uses an emission inventory that depends of the time of day and the day of week, and a de- position velocity based on the local meteorology and land surface type. In contrast to the surface-atmosphere exchange parameterizations currently used in AURAMS, the net exchange of ammonia between the atmosphere and some surfaces is thought to be governed in part by the equilibrium between the atmospheric ammonia and the ammonium in plant apoplastic fluid (Schjoerring et al., 1998). In this pathway, ammonia emissions occur if the stomatal compensation point is greater than the atmospheric mixing ratios (Farquhar et al., 1980). Conversely, deposition will occur if the compensation point is lower than the atmospheric mixing ratios. Thus atmospheric gas phase ammonia is simultaneously participating in two equilibria: one with atmospheric particulate ammonium, and one with a pool of ammonium at the surface. If the condensation sink increases (e.g. by an increase in aerosol sulfate), the atmosphere is depleted of ammonia, potentially lowering the ambient mixing ratios below the compensation point, and triggering emissions from the plants and soil. This phenomenon was previously implied in a study by Sutton et al. (1994) where high emissions of $\mathrm{NH}_{3}$ were observed at the same time as high $\mathrm{SO}_{2}$ concentrations, from which the authors inferred acidic aerosol loadings.

One interpretation of the difference between the measured and modelled distributions of gas fraction shown in Fig. 8 is that in the real atmosphere, the direction of the surface flux of ammonia may depend on the atmospheric mixing ratio of $\mathrm{NH}_{3}$, thereby buffering the gas fraction. In the current version of AURAMS, the dry deposition flux of ammonia depends on the ambient ammonia mixing ratios. However, the magnitude of AURAMS' ammonia emissions flux is not coupled to the model's ambient ammonia mixing ratios. AURAMS does not currently include a bi-directional flux parameterization for ammonia, so when a large amount of sulfate exists in the atmosphere, all of the ammonia condenses, generating a significant number of points in the model at zero gas fraction. However, bi-directional flux suggests that the depletion of gas phase ammonia by condensation would lead to larger fluxes from the surface to the atmosphere, replenishing the gas phase ammonia and moving the observations more toward the middle of the histogram in Fig. 8. Rather than defining the emission and deposition terms in the model as separate processes, these can be represented by a net flux, whose direction depends on how ambient ammonia mixing ratios compare to a compensation point. To accurately represent this process in the model, it would have to be incorporated online so that it was fully coupled with all of the other source and sink processes. There have been many recent papers discussing methods to fully couple the bi-directional flux of ammonia into a chemical transport model (van Pul et al., 2009; Kruit et al., 2010; Massad et al., 2010; Zhang et al., 2010), wherein the ammonia emissions flux is to some extent dependent on the mixing ratios of ammonia present in the atmosphere.

As a simple sensitivity test of this concept, starting with the AURAMS output at Harrow, we successively replaced all 


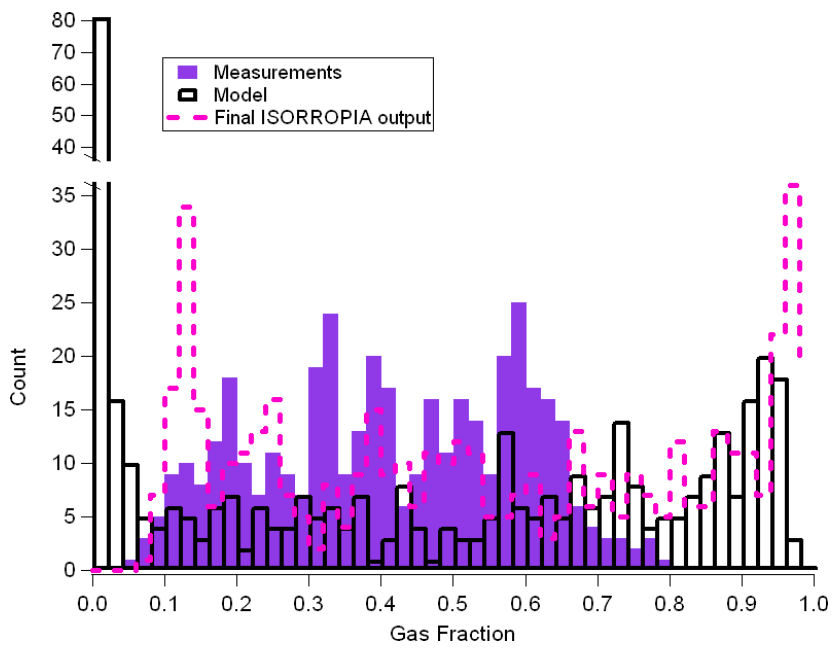

Fig. 10. Histogram of the measured and modelled gas fraction from Figure 8, now including the result of final offline run of ISORROPIA, iterated until the aerosol was fully neutralized and the gas phase concentration was equal to a pre-determined compensation point.

the model gas phase ammonia values with a single compensation point value, and then repartitioned the total ammonia $\left(\mathrm{NH}_{\mathrm{x}}\right)$ offline using the ISORROPIA thermodynamic model. For a single compensation point value, we performed several iterations in ISORROPIA each time replacing the calculated gas phase amounts in the output with the compensation point as the input of the next run. Eventually, the output converges to the compensation point for gas phase ammonia and enough particulate ammonium for fully neutralized aerosol. Single compensation point values of $0.5,1.0,1.5$ and $1.7 \mu \mathrm{g} \mathrm{m}^{-3}$ were tested, chosen to reflect the vegetation type and estimated nitrogen content at our measurement site. The results shown in Fig. 10 were achieved using a compensation point of $1 \mu \mathrm{g} \mathrm{m}^{-3}$ and indicate that this approach was successful at drawing down the number of zero gas phase points in the model histogram. The number of high gas fraction cases increased when all of the added $\mathrm{NH}_{\mathrm{x}}$ remained as $\mathrm{NH}_{3}$. This tended to occur in situations where modeled sulfate and nitrate were biased low and could not accommodate additional ammonium. We also performed the same test as above, but with a temperature dependent compensation point as described by Nemitz et al. (2001). Here, we used an average value for the stomatal apoplastic ratio $\left(\Gamma_{s}\right)$ from Kruit et al. (2010). However, this approach does not accurately reflect our data, as a temperature dependent compensation point will predict the highest $\mathrm{NH}_{3}$ in the middle of the day, contrary to what was observed (Fig. 4). Possible reasons for this inconsistency could be that there is a time-of-day dependency to the wind direction, and hence upwind $\Gamma_{s}$, or that the full coupling of the gas-particle partitioning and surfaceatmosphere exchange of ammonia is not achieved through the full boundary layer instantaneously. While this simpli- fied approach does not reproduce the observations perfectly, it does imply that the inclusion of a bi-directional flux of ammonia may improve model-measurement agreement regarding the gas fraction of ammonia.

\section{Conclusions}

Gas phase mixing ratios of ammonia in an agricultural region in Southwestern Ontario averaged $2.5 \mathrm{ppb}$, with sharp spikes at night, likely from traffic. The diurnal profile of ammonia shows an increase in the early morning that may be due to volatilization from the surface, emissions from plant/soil or mixing down of stagnant air upon the breakup of the nocturnal boundary layer. Ammonia decreased in the afternoon as a result of condensation to aerosol containing high levels of sulfate. Observations showed the ratio of $\mathrm{NH}_{\mathrm{x}} / \mathrm{SO}_{4}^{2-}$ exceeded 2 most of the time, however, the regional model AURAMS was consistently biased very low in regards to the neutralization of sulfate at this site. These observations in an agricultural region suggest that the presence of large amounts of acidic sulfate aerosol in the atmosphere can induce high net emission rates of ammonia due to bi-directional flux. This analysis is the first to use simultaneous observations of atmospheric ammonia and ammonium combined with high resolution models to examine the coupling between gas-particle and surface-atmosphere equilibria governing ammonia mixing ratios. Our observations indicate that in regions where area-wide sources dominate, the accuracy of chemical transport models may be improved by including a fully coupled bi-directional flux parameterization to make accurate predictions of atmospheric ammonia. Because the timescales of the gas-particle and surface-atmosphere equilibrium processes are likely similar, and comparable to the times required for vertical mixing, simultaneous measurements of the concentrations, and ideally fluxes, of gas phase $\mathrm{NH}_{3}$, and particulate ammonium are needed to provide full observational constraints. Additionally, this work suggests that the emission rates of ammonia in some regions may depend on the atmospheric mixing ratios of not only ammonia, but also the mass loadings and composition of aerosol. This will have implications both for efforts to model ammonia emissions and also to implement ammonia emission reductions to control $\mathrm{PM}_{2.5}$.

Acknowledgements. The QC-TILDAS and AIM-IC were available through infrastructure support to J.G.M. from the Canada Foundation for Innovation and the Ontario Research Fund. R.A.E. was supported by the Research Affiliate Program at Environment Canada (2008-2010) while carrying out much of this work. The authors acknowledge Agriculture and Agri-food Canada for providing the site at Harrow and $\mathrm{Al}$ Melanson, from the Ontario Ministry of Environment, for his efforts in coordinating the site infrastructure and logistics.

Edited by: D. Hastie 


\section{References}

Asman, W. A. H., Sutton, M. A., and Schjorring, J. K.: Ammonia: emission, atmospheric transport and deposition, New Phytologist, 139, 27-48, 1998.

Bash, J. O., Walker, J. T., Katul, G. G., Jones, M. R., Nemitz, E., and Robarg, W. P.: Estimation of In-Canopy Ammonia Sources and Sinks in a Fertilized Zea mays Field, Environ. Sci. Tech., 44, 1683-1689, 2010.

Bobbink, R., Hornung, M., and Roelofs, J. G. M.: The effects of air-borne nitrogen pollutants on species diversity in natural and semi-natural European vegetation, J. Ecol., 86, 717-738, 1998.

Brost, R. A., Delany, A. C., and Huebert, B. J.: Numerical Modeling of Concentrations and Fluxes of $\mathrm{HNO}_{3}, \mathrm{NH}_{3}$, and $\mathrm{NH}_{4} \mathrm{NO}_{3}$ near the Surface, J. Geophys. Res.-Atmos., 93, 7137-7152, 1988.

Carolina Environmental Program, Sparse Matrix Operator Kernel Emission (SMOKE) modelling system, University of North Carolina, Carolina Environmental Programs, Chapel Hill, NC, USA, http://www.smoke-model.org/index.cfm, 2003.

Cheng, Y.-H. and Tsai, C.-J.: Evaporation loss of ammonium nitrate particles during filter sampling, J. Aerosol Sci., 28, 1553-1567, 1997.

Cho, S., Makar, P. A., Lee, W. S., Herage, T., Liggio, J., Li, S. M., Wiens, B., and Graham, L.: Evaluation of a unified regional airquality modeling system (AURAMS) using PrAIRie2005 field study data: The effects of emissions data accuracy on particle sulphate predictions, Atmos. Environ., 43, 1864-1877, 2009.

Chow, J. C., Watson, J. G., Lowenthal, D. H., Egami, R. T., Solomon, P. A., Thuillier, R. H., Magliano, K., and Ranzieri, A.: Spatial and temporal variations of particulate precursor gases and photochemical reaction products during SJVAQS/AUSPEX ozone episodes, Atmos. Environ., 32, 2835-2844, 1998.

Cote, J., Gravel, S., Methot, A., Patoine, A., Roch, M., and Staniforth, A.: The operational CMC-MRB Global Environmental Multiscale (GEM) model. Part I: Design considerations and formulation, Mon. Weather Rev., 126, 1373-1395, 1998.

Ellis, R. A., Murphy, J. G., Pattey, E., van Haarlem, R., O’Brien, J. M., and Herndon, S. C.: Characterizing a Quantum Cascade Tunable Infrared Laser Differential Absorption Spectrometer (QCTILDAS) for measurements of atmospheric ammonia, Atmos. Meas. Tech., 3, 397-406, doi:10.5194/amt-10-397-2010, 2010.

Erisman, J. W. and Wyers, G. P.: Continuous Measurements of Surface Exchange of $\mathrm{SO}_{2}$ and $\mathrm{NH}_{3}$ - Implications for Their Possible Interaction in the Deposition Process, Atmos. Environ. Part A, 27, 1937-1949, 1993.

Erisman, J. W., Bleeker, A., Hensen, A., and Vermeulen, A.: Agricultural air quality in Europe and the future perspectives, Atmos. Environ., 42, 3209-3217, 2008.

Fangmeier, A., Hadwigerfangmeier, A., Vandereerden, L., and Jager, H. J.: Effects of Atmospheric Ammonia on Vegetation - a Review, Environ. Pollut., 86, 43-82, 1994.

Farquhar, G. D., Firth, P. M., Wetselaar, R., and Weir, B.: On the Gaseous Exchange of Ammonia between Leaves and the Environment - Determination of the Ammonia Compensation Point, Plant Physiol., 66, 710-714, 1980.

Finlayson-Pitts, B. J. and Pitts, J. N.: Chemistry of the upper and lower atmosphere: theory, experiments, and applications., Academic Press, San Diego, CA, USA, 969 pp., 1999.

Flechard, C. R., Fowler, D., Sutton, M. A., and Cape, J. N.: A dynamic chemical model of bi-directional ammonia exchange between semi-natural vegetation and the atmosphere, Q. J. Roy. Meteor. Soc., 125, 2611-2641, 1999.

Galloway, J. N., Aber, J. D., Erisman, J. W., Seitzinger, S. P., Howarth, R. W., Cowling, E. B., and Cosby, B. J.: The nitrogen cascade, Bioscience, 53, 341-356, 2003.

Gong, W. M., Dastoor, A. P., Bouchet, V. S., Gong, S. L., Makar, P. A., Moran, M. D., Pabla, B., Menard, S., Crevier, L. P., Cousineau, S., and Venkatesh, S.: Cloud processing of gases and aerosols in a regional air quality model (AURAMS), Atmos. Res., 82, 248-275, 2006.

Gras, J. L.: A Field Comparison of 2 Atmospheric Ammonia Sampling Techniques, Tellus B-Chemi. Phys. Meteorol., 36, 38-43, 1984.

Harrison, R. M., Rapsomanikis, S., and Turnbull, A.: Land Surface Exchange in a Chemically-Reactive System - Surface Fluxes of $\mathrm{HNO}_{3}, \mathrm{HCl}$ and $\mathrm{NH}_{3}$, Atmos. Environ., 23, 1795-1800, 1989.

Herndon, S. C., Zahniser, M. S., Nelson, D. D., Shorter, J., McManus, J. B., Jimenez, R., Warneke, C., and de Gouw, J. A. Airborne measurements of $\mathrm{HCHO}$ and $\mathrm{HCOOH}$ during the New England Air Quality Study 2004 using a pulsed quantum cascade laser spectrometer, J. Geophys. Res.-Atmos., 112, D10S03, doi:10.1029/2006JD007600, 2007.

Houyoux, M. R., Vukovich, J. M., Coats, C. J., Wheeler, N. J. M., and Kasibhatla, P. S.: Emission inventory development and processing for the Seasonal Model for Regional Air Quality (SMRAQ) project, J. Geophys. Res.-Atmos., 105, 9079-9090, 2000.

IPCC: Climate Change 2007: The Physical Science Basis: Contribution of Working Group I to the Fourth Assessment Report of the Intergovernmental Panel on Climate Change, edited by: Solomon, S., Qin, D., Manning, M., Chen, Z., Marquis, M., Averyt, K. B., Tignor, M., and Miller, H. L., Cambridge University Press, Cambridge, 996 pp., 2007.

Kean, A. J., Littlejohn, D., Ban-Weiss, G. A., Harley, R. A., Kirchstetter, T. W., and Lunden, M. M.: Trends in on-road vehicle emissions of ammonia, Atmos. Environ., 43, 1565-1570, 2009.

Kramm, G. and Dlugi, R.: Modeling of the Vertical Fluxes of NitricAcid, Ammonia, and Ammonium-Nitrate, J. Atmos. Chem., 18, 319-357, 1994.

Kruit, R. J. W., van Pul, W. A. J., Otjes, R. P., Hofschreuder, P., Jacobs, A. F. G., and Holtslag, A. A. M.: Ammonia fluxes and derived canopy compensation points over non-fertilized agricultural grassland in The Netherlands using the new gradient ammonia - high accuracy - monitor (GRAHAM), Atmos. Environ., 41, 1275-1287, 2007.

Kruit, R. J. W., van Pul, W. A. J., Sauter, F. J., van den Broek, M., Nemitz, E., Sutton, M. A., Krol, M., and Holtslag, A. A. M.: Modeling the surface-atmosphere exchange of ammonia, Atmos. Environ., 44, 945-957, 2010.

Krupa, S. V.: Effects of atmospheric ammonia (NH3) on terrestrial vegetation: a review, Environ. Pollut., 124, 179-221, 2003.

Li, Y. Q., Schwab, J. J., and Demerjian, K. L.: Measurements of ambient ammonia using a tunable diode laser absorption spectrometer: Characteristics of ambient ammonia emissions in an urban area of New York City, J. Geophys. Res.-Atmos., 111, D10S02, doi:10.1029/2005JD006275, 2006.

Livingston, C., Rieger, P., and Winer, A.: Ammonia emissions from a representative in-use fleet of light and medium-duty vehicles in the California South Coast Air Basin, Atmos. Environ., 43, 3326-3333, 2009. 
Makar, P. A., Bouchet, V. S., and Nenes, A.: Inorganic chemistry calculations using HETV-a vectorized solver for the $\mathrm{SO}_{4}^{2-}$ $\mathrm{NO}_{3}^{-}-\mathrm{NH}_{4}^{+}$system based on the ISORROPIA algorithms, Atmos. Environ., 37, 2279-2294, 2003.

Makar, P. A., Moran, M. D., Zheng, Q., Cousineau, S., Sassi, M., Duhamel, A., Besner, M., Davignon, D., Crevier, L.-P., and Bouchet, V. S.: Modelling the impacts of ammonia emissions reductions on North American air quality, Atmos. Chem. Phys., 9, 7183-7212, doi:10.5194/acp-9-7183-2009, 2009.

Makar, P. A., Zhang, J., Gong, W., Stroud, C., Sills, D., Hayden, K. L., Brook, J., Levy, I., Mihele, C., Moran, M. D., Tarasick, D. W., He, H., and Plummer, D.: Mass tracking for chemical analysis: the causes of ozone formation in southern Ontario during BAQS-Met 2007, Atmos. Chem. Phys., 10, 11151-11173, doi:10.5194/acp-10-11151-2010, 2010.

Massad, R. S., Nemitz, E., and Sutton, M. A.: Review and parameterisation of bi-directional ammonia exchange between vegetation and the atmosphere, Atmos. Chem. Phys., 10, 10359-10386, doi:10.5194/acp-10-10359-2010, 2010.

McCalley, C. K. and Sparks, J. P.: Controls over nitric oxide and ammonia emissions from Mojave Desert soils, Oecologia, 156, 871-881, 2008.

McManus, J. B., Nelson, D. D., Shorter, J., Zahniser, M., Mueller, A., Bonetti, Y., Beck, M., Hofstetter, D., and Faist, J.: Quantum cascade lasers for open and closed path measurement of atmospheric trace gases, Diode Las. Appl. Atmos. Sens., 4817, 22-33, 2002.

Nelson, D. D., McManus, B., Urbanski, S., Herndon, S., and Zahniser, M. S.: High precision measurements of atmospheric nitrous oxide and methane using thermoelectrically cooled midinfrared quantum cascade lasers and detectors, Spectrochimica Acta Part a-Molecular and Biomolecular Spectroscopy, 60, 3325-3335, 2004.

Nemitz, E., Milford, C., and Sutton, M. A.: A two-layer canopy compensation point model for describing bi-directional biosphere-atmosphere exchange of ammonia, Q. J. Roy. Meteorol. Soc., 127, 815-833, 2001.

Nemitz, E., Sutton, M. A., Wyers, G. P., Otjes, R. P., Mennen, M. G., van Putten, E. M., and Gallagher, M. W.: Gas-particle interactions above a Dutch heathland: II. Concentrations and surface exchange fluxes of atmospheric particles, Atmos. Chem. Phys., 4, 1007-1024, doi:10.5194/acp-4-1007-2004, 2004.

Nenes, A., Pandis, S. N., and Pilinis, C.: ISORROPIA: A new thermodynamic equilibrium model for multiphase multicomponent inorganic aerosols, Aqua. Geochem., 4, 123-152, 1998.

Nowak, J. B., Huey, L. G., Russell, A. G., Tian, D., Neuman, J. A., Orsini, D., Sjostedt, S. J., Sullivan, A. P., Tanner, D. J., Weber, R. J., Nenes, A., Edgerton, E., and Fehsenfeld, F. C.: Analysis of urban gas phase ammonia measurements from the 2002 Atlanta Aerosol Nucleation and Real-Time Characterization Experiment (ANARChE), J. Geophys. Res.-Atmos., 111, D17308, doi:10.1029/2006JD007113, 2006.

Nowak, J. B., Neuman, J. A., Bahreini, R., Brock, C. A., Middlebrook, A. M., Wollny, A. G., Holloway, J. S., Peischl, J., Ryerson, T. B., and Fehsenfeld, F. C.: Airborne observations of ammonia and ammonium nitrate formation over Houston, Texas, J. Geophys. Res.-Atmos., 115, D22304, doi:10.1029/2010JD014195, 2010.

National Pollutant Release Inventory: 2007 Ammonia Emissions for Canada: http://ec.gc.ca/pdb/websol/emissions/ap/ap_query_ e.cfm, last access: 26 July 2010.

Pinder, R. W., Adams, P. J., and Pandis, S. N.: Ammonia emission controls as a cost-effective strategy for reducing atmospheric particulate matter in the eastern United States, Environ. Sci. Tech., 41, 380-386, 2007.

Pinder, R. W., Gilliland, A. B., and Dennis, R. L.: Environmental impact of atmospheric NH3 emissions under present and future conditions in the eastern United States, Geophys. Res. Lett., 35, L12808, doi:10.1029/2008GL033732, 2008.

Pope, C. A., Burnett, R. T., Thun, M. J., Calle, E. E., Krewski, D., Ito, K., and Thurston, G. D.: Lung cancer, cardiopulmonary mortality, and long-term exposure to fine particulate air pollution, J. Am. Med. Assoc., 287, 1132-1141, 2002.

Roelle, P. A. and Aneja, V. P.: Characterization of ammonia emissions from soils in the upper coastal plain, North Carolina, Atmos. Environ., 36, 1087-1097, 2002.

Sakurai, T., Fujita, S., Hayami, H., and Furuhashi, N.: A case study of high ammonia concentration in the nighttime by means of modeling analysis in the Kanto region of Japan, Atmos. Environ., 37, 4461-4465, 2003.

Schaap, M., Otjes, R. P., and Weijers, E. P.: Illustrating the benefit of using hourly monitoring data on secondary inorganic aerosol and its precursors for model evaluation, Atmos. Chem. Phys. Discuss., 10, 12341-12370, doi:10.5194/acpd-10-12341-2010, 2010.

Schjoerring, J. K., Husted, S., and Mattsson, M.: Physiological parameters controlling plant-atmosphere ammonia exchange, Atmos. Environ., 32, 491-498, 1998.

Smyth, S. C., Jiang, W. M., Roth, H., Moran, M. D., Makar, P. A., Yang, F. Q., Bouchet, V. S., and Landry, H.: A comparative performance evaluation of the AURAMS and CMAQ air-quality modelling systems, Atmos. Environ., 43, 1059-1070, 2009.

Stelson, A. W. and Seinfeld, J. H.: Relative-Humidity and Temperature-Dependence of the Ammonium-Nitrate Dissociation-Constant, Atmos. Environ., 16, 983-992, 1982.

Stroud, C. A., Morneau, G., Makar, P. A., Moran, M. D., Gong, W., Pabla, B., Zhang, J., Bouchet, V. S., Fox, D., Venkatesh, S., Wang, D., and Dann, T.: OH-reactivity of volatile organic compounds at urban and rural sites across Canada: Evaluation of air quality model predictions using speciated VOC measurements, Atmos. Environ., 42, 7746-7756, 2008.

Sutton, M. A., Fowler, D., and Moncrieff, J. B.: The Exchange of Atmospheric Ammonia with Vegetated Surfaces .1. Unfertilized Vegetation, Q. J. Roy. Meteorol. Soc., 119, 1023-1045, 1993.

Sutton, M. A., Asman, W. A. H., and Schjorring, J. K.: Dry Deposition of Reduced Nitrogen, Tellus B, 46, 255-273, 1994.

Sutton, M. A., Schjorring, J. K., and Wyers, G. P.: Plant Atmosphere Exchange of Ammonia, Philos. T. Roy. Soc. A, 351, 261276, 1995.

Sutton, M. A., Nemitz, E., Milford, C., Campbell, C., Erisman, J. W., Hensen, A., Cellier, P., David, M., Loubet, B., Personne, E., Schjoerring, J. K., Mattsson, M., Dorsey, J. R., Gallagher, M. W., Horvath, L., Weidinger, T., Meszaros, R., Dammgen, U., Neftel, A., Herrmann, B., Lehman, B. E., Flechard, C., and Burkhardt, J.: Dynamics of ammonia exchange with cut grassland: synthesis of results and conclusions of the GRAMINAE Integrated Experiment, Biogeosciences, 6, 2907-2934, doi:10.5194/bg-6-29072009, 2009. 
Trebs, I., Meixner, F. X., Slanina, J., Otjes, R., Jongejan, P., and Andreae, M. O.: Real-time measurements of ammonia, acidic trace gases and water-soluble inorganic aerosol species at a rural site in the Amazon Basin, Atmos. Chem. Phys., 4, 967-987, doi:10.5194/acp-4-967-2004, 2004.

Tsimpidi, A. P., Karydis, V. A., and Pandis, S. N.: Response of inorganic fine particulate matter to emission changes of sulfur dioxide and ammonia: The eastern United States as a case study, J.e Air Waste Manage. Assoc., 57, 1489-1498, 2007.

US Environmental Protection Agency: National Emissions Inventory (NEI) Air Pollutant Emissions Trends Data: http://www.epa. gov/ttn/chief/trends/, last access: 29 July 2009.

van Pul, A., Hertel, O., Geels, C., Dore, A. J., Vieno, M., van Jaarsveld, H. A., Bergstrom, R., Schaap, M., and Fagerli, H.: Modelling of the Atmospheric Transport and Deposition of Ammonia at a National and Regional Scale, Atmos. Ammonia, 301358, 2009.

Walker, J. T., Robarge, W. P., Wu, Y., and Meyers, T. P.: Measurement of bi-directional ammonia fluxes over soybean using the modified Bowen-ratio technique, Agr. Forest Meterol., 138, 5468, 2006.

Whitehead, J. D., Longley, I. D., and Gallagher, M. W.: Seasonal and diurnal variation in atmospheric ammonia in an urban environment measured using a quantum cascade laser absorption spectrometer, Water Air Soil Pollut., 183, 317-329, 2007.
Whitehead, J. D., Twigg, M., Famulari, D., Nemitz, E., Sutton, M. A., Gallagher, M. W., and Fowler, D.: Evaluation of laser absorption spectroscopic techniques for eddy covariance flux measurements of ammonia, Environ. Sci. Tech., 42, 2041-2046, 2008.

Wolff, V., Trebs, I., Foken, T., and Meixner, F. X.: Exchange of reactive nitrogen compounds: concentrations and fluxes of total ammonium and total nitrate above a spruce canopy, Biogeosciences, 7, 1729-1744, doi:10.5194/bg-7-1729-2010, 2010.

Wu, Y. H., Walker, J., Schwede, D., Peters-Lidard, C., Dennis, R., and Robarge, W.: A new model of bi-directional ammonia exchange between the atmosphere and biosphere: Ammonia stomatal compensation point, Agr. Forest Meterol., 149, 263-280, 2009.

Zhang, L., Wright, L. P., and Asman, W. A. H.: Bi-directional airsurface exchange of atmospheric ammonia - A review of measurements and a development of a big-leaf model for applications in regional-scale air-quality models, J. Geophys. Res, D20310, doi:10.1029/2009JD013589, 2010. 